\title{
Reproductive Biology and Flowering of Feijoa (Acca sellowiana (Berg) Burret) in Areas of Marginal Occurrence
}

\author{
Joel Donazzolo ${ }^{1}$, Eliza Luana Charneski Turra ${ }^{2}$, Larissa Corradi Voss², Moeses Andrigo Danner ${ }^{2}$, \\ Idemir Citadin ${ }^{2} \&$ Rubens Onofre Nodari ${ }^{3}$ \\ ${ }^{1}$ Department of Agronomy, Federal University of Technology-Paraná, Dois Vizinhos, PR, Brazil \\ ${ }^{2}$ Department of Agronomy, Federal University of Technology-Paraná, Pato Branco, PR, Brazil \\ ${ }^{3}$ Graduate Program in Plant Genetic Resources, Federal University of Santa Catarina, Florianópolis, SC, Brazil \\ Correspondence: Joel Donazzolo, Graduate Program in Agroecosystems, Department of Agronomy, Federal \\ University of Technology-Paraná, Estrada Para Boa Esperança, Km 04, 85660-000, Dois Vizinhos, Paraná, \\ Brazil. Tel: 55-463-536-8428. E-mail: joel@utfpr.edu.br
}

Received: February 9, 2019

Accepted: April 2, 2019 Online Published: June 15, 2019

doi:10.5539/jas.v11n8p156

URL: https://doi.org/10.5539/jas.v11n8p156

\begin{abstract}
Studies of feijoa adaptability in different locations, with specific weather conditions can be useful for the cultivation of the species. The objective of this work was to study aspects of reproductive biology (pollen viability and fruit set under different methods of pollination) and flowering phenology of feijoa in regions of marginal species occurrence. Progenies of five different crosses were evaluated in 2011 in Pato Branco and Dois Vizinhos, Paraná, Brazil. Effective fruit set was low with manual self-pollination and open pollination, but was higher with manual cross-pollination, demonstrating a lack of pollinators or even self-incompatibility in some progenies. For both sites, pollen viability was extremely low and atypical for the species. The flowering period of feijoa started earlier and was extended in these marginal regions. Manual pollination is required for a good fruit set.
\end{abstract}

Keywords: adaptability, pineaple-guava, pollen viability, pollination

\section{Introduction}

Feijoa, known in Brazil as "goiabeira-serrana", is classified as Acca sellowiana (Berg) Burret (Mattos, 1986) and is defined by the Ministry of the Environment as a native species that is potentially important for commercial cultivation (Coradin, Siminski, \& Reis, 2011). Its fruits can be consumed fresh or processed (Thorp \& Bieleski, 2002). This tree belongs to the Myrtaceae family, and is native to the Brazilian southern plateau, frequently found in forests along with Paraná pines (Araucaria angustifolia), or in Araucaria Moist Forests (Lorenzini, Boff, Rech, \& Boff, 2007). It also occurs in the South of Brazil, and in Northern Uruguay (Mattos, 1986; Thorp \& Bieleski, 2002; Vignale \& Bisio, 2005), which are the regions considered the center of its origin and diversity.

In studies on feijoa adaptability in different locations, Ducroquet, Hickel, and Nodari (2000) believed that the high-altitude regions in Paraná, Santa Catarina and Rio Grande do Sul states, Brazil, could be suitable for cultivation of the species. The four cultivars officially released in Brazil-Alcântara, Nonante, Helena and Mattos are recommended only for altitudes above 1,200 m (Ducroquet et al., 2007; Ducroquet, Nunes, Guerra, \& Nodari, 2008). However, the species has been successfully cultivated in ecosystems that are different to those characterized as its center of origin, such as in Colombia, where more than 600 ha are cultivated, and in New Zealand, where about 500 ha are cultivated (Amarante, 2017), making them the largest world producers (Thorp \& Bieleski, 2002). Feijoa is also present in countries such as Turkey (Beyhan \& Eyduran, 2011), Ukraine (Yezhov et al., 2005) and China (Xiong, Zou, Yuan, Zhang, \& Tan, 2016), among others. This fact highlights the potential plasticity of the species to adapt to different environmental conditions, an interesting characteristic in times of intense climatic changes. In Brazil, there are initiatives to adapt the cultivation this species outside of the preferred regions (Santos, Donazzolo, Guries, Peroni, \& Nodari, 2018; Donazzolo, Ornellas, Bertoldo, \& Nodari, 2014).

In its center of origin, feijoa has a well-defined vegetation cycle, starting its sprouting in mid-September and flowering from October to November, with the identification of flowering axillary buds before this period being quite difficult (Ducroquet et al., 2000; Ducroquet \& Hickel, 1991). Recently, in the Bogotá region, six distinct phases of phenological growth of two different feijoa cultivars were identified according to the $\mathrm{BBCH}$ 
(Biologische Bundesantalt, Bundessortenamt und Chemische Industrie): bud growth, leaf development, shoot development, emergence of flowers, flowering and fruiting development (Ramírez \& Kallarackal, 2018). This scale can aid in the identification of vegetative and flowering axillary buds in the regions of origin.

Feijoa has late-acting self-incompatibility in some genotypes, and it requires cross-pollination among genetically distinct individuals (Santos et al., 2007; Finatto et al., 2011), which makes studying the behavior of its reproductive biology important in places of potential cultivation, since pollination is a preponderant factor for fruit set success (Ramírez \& Kallarackal, 2017). Combinations of climatic conditions such as temperature, precipitation and solar radiation, among others, can influence plant phenology (Fischer, Ramírez, \& Almanza-Merchán, 2012; Parra-Coronado, Fischer, \& Camacho-Tamayo, 2015). Thus, studies of its phenologogy and reproductive biology are important, since they predict stages of plant development, providing evaluation of the performance and adaptation of cultivars to certain climatic conditions in the cultivation areas (Miranda, Santesteban, \& Royo, 2013). These studies help both in the selection of new adapted cultivars and in the choice of new cultivation environments, which facilitates the planning and management of orchards.

Thus, the objective of this study was to characterize aspects of the reproductive biology and flowering phenology of feijoa in areas of marginal occurrence of the species.

\section{Material and Methods}

Feijoa plants were established in 2011 at two experimental orchards of the Federal University of Technology-Paraná, one each at the Pato Branco Campus $\left(26^{\circ} 41^{\prime} \mathrm{S}, 56^{\circ} 07^{\prime} \mathrm{W} ; 730 \mathrm{~m}\right.$ a.s.1.) and the Dois Vizinhos Campus $\left(25^{\circ} 42^{\prime} 52^{\prime \prime} \mathrm{S}, 53^{\circ} \mathrm{W} ; 530 \mathrm{~m}\right.$ a.s.l.). The orchards were established in randomized blocks, containing four replications, with each replication composed of three plants, and a spacing of $4.5 \mathrm{~m} \times 3.0 \mathrm{~m}$. There was a border line of plants surrounding experimental site, which were not evaluated. The soil of Pato Branco orchard is classified as a Red Nitosol (Bhering et al., 2008), while the soil of the Dois Vizinhos orchard is classified as a Red Latosol (Embrapa, 2006). The climate for both sites is Cfa (Köppen classification), with well distributed precipitation throughout the months of the year, surpassing $1800 \mathrm{~mm}$ annually. The annual average temperature in Dois Vizinhos is between 19 and $20^{\circ} \mathrm{C}$ and in Pato Branco it is between 18 and $19{ }^{\circ} \mathrm{C}$ (Iapar, 2017). The precipitation and temperature observed during the study period are shown in Figure 1.

The evaluations were performed on progenies of five crossings at Pato Branco (Alcântara $\times$ Nonante, Alcântara $\times$ Helena, Nonante $\times$ Alcântara, Nonante $\times$ Nonante, Nonante $\times$ Helena) and five at Dois Vizinhos (Alcântara $\times$ Nonante, Alcântara $\times$ Helena, Alcântara $\times$ Mattos, Helena $\times$ Nonante, Helena $\times$ Mattos), which are part of a diallel crossing between the four cultivars within the genetic improvement program.

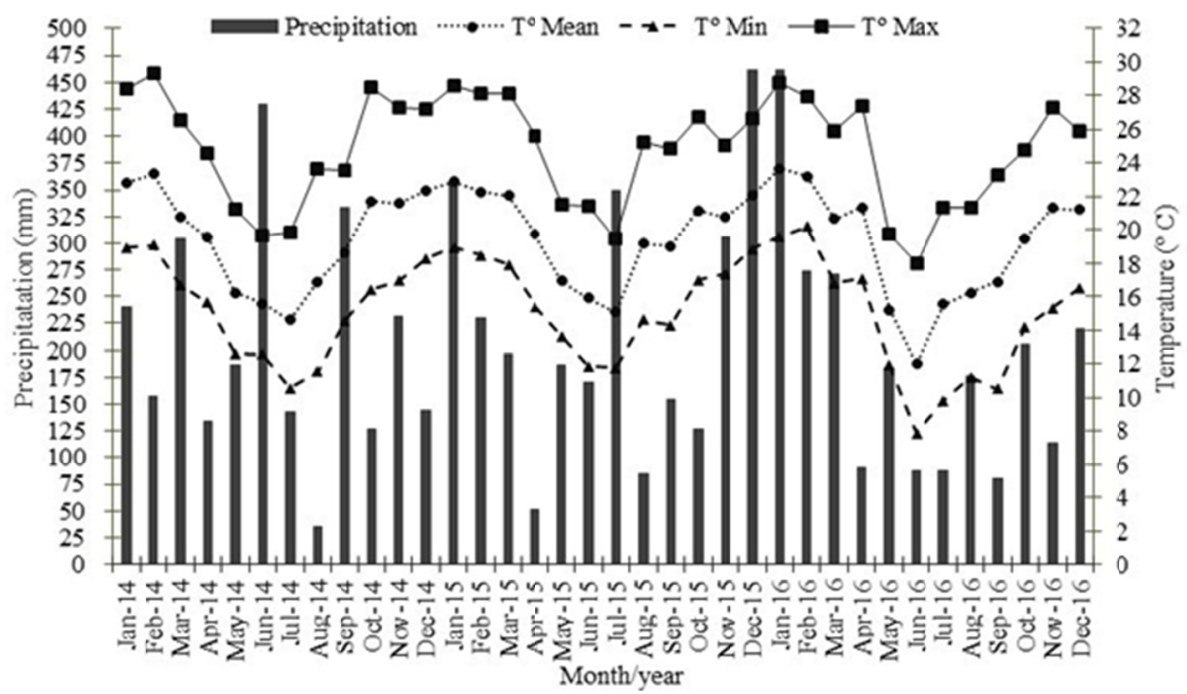




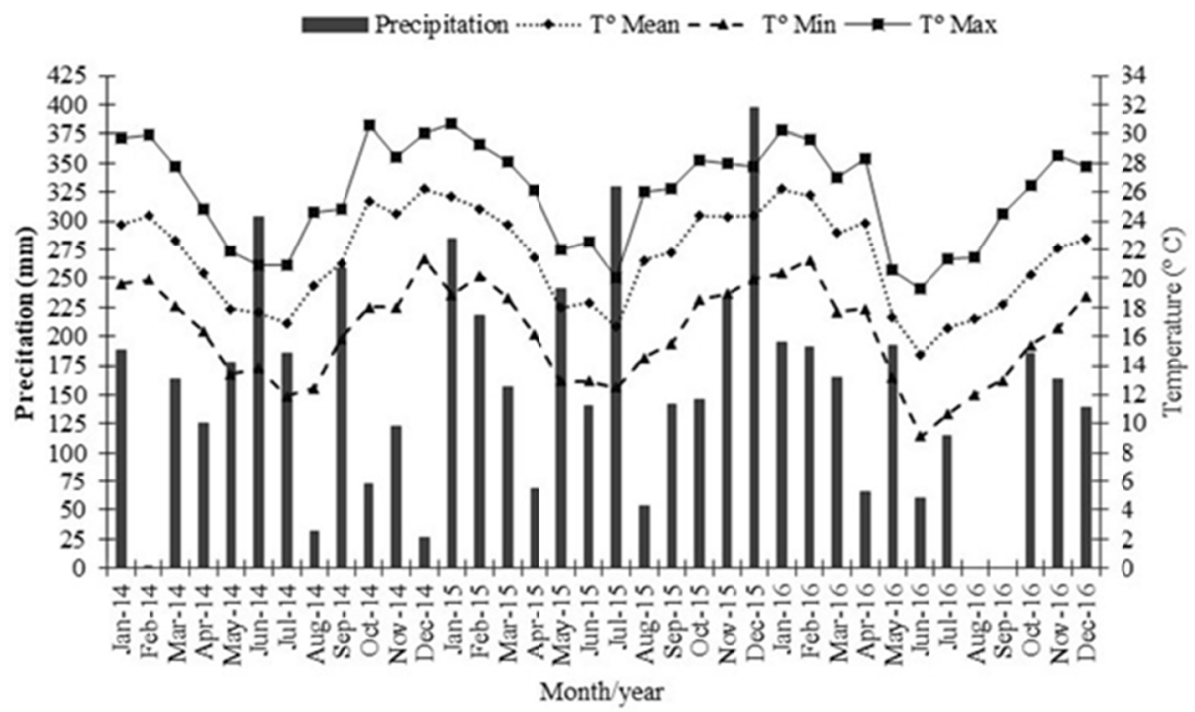

Figure 1. Precipitation and temperature for Pato Branco (above) and Dois Vizinhos (below) from January 2014 to December 2016. Source: Simepar and INMET, respectively

The evaluations of phenology and flowering were performed during the 2014/2015, 2015/2016 and 2016/2017 cycles, to compare between years and between sites. The flower buds were assessed weekly, in order to characterize the evolution of the phenological stages, as described by Ducroquet and Hickel (1991), until all were in the last phenological stage, when only the sepals remain. The analysis of flowering phenology and fruit set in Pato Branco was performed during the 2014/2015 and 2015/2016 cycles, on two branches previously selected from a plant from each replication, in each treatment, comprising a total of 20 plants. For the 2016/2017 cycle, all plants from useful plots were assessed. In Dois Vizinhos, all the plants were assessed during the three evaluated cycles. The obtained data were tabulated, linking them with the relevant rainfall and average air temperature values.

To analyze self-incompatibility, three treatments were used: (T1) manual self-pollination, with pollen from the same plant (number of pollinated flowers: 207 and 27 for Pato Branco and Dois Vizinhos, respectively); (T2) manual cross-pollination, using a mix of pollen from three other genotypes, distinct to the ones in the experiment (number of pollinated flowers $=194$ and 36 for Pato Branco and Dois Vizinhos, respectively) and (T3) open pollination, submitted to open pollination conditions in the experimental areas (number of evaluated flowers: 382 and 137 for Pato Branco and Dois Vizinhos, respectively). The T1 and T2 flowers were marked in the balloon stage to identify each treatment, and bagged with waxed white paper, in order to prevent natural pollination. The next day, before anther dehiscence, the flowers were emasculated, pollinated, and bagged again. For T3, the buds were marked and counted, and no other procedure was performed until the assessment. In order to confirm the occurrence of self-incompatibility, and verify its influence on fruit formation, the effective fruit set of the treatments was calculated using the following formula: $\mathrm{EF}=(\mathrm{NF} / \mathrm{NFI}) \times 100$, in which, $\mathrm{NF}=$ total number of fruits, and NFI = total number of pollinated flowers. The data were expressed in a graph, with the percentage found for the effective fruit set of each genotype and for each method of pollination. Frequency data were subjected to association analysis in a contingency table with chi-square test, using the Past software (Hammer, Harper, \& Ryan, 2001).

Pollen viability of the genotypes was tested through in vitro germination. Branches with flowers were collected in the balloon stage, transported to the laboratory and left in water until flower opening and anther dehiscence. The anthers were manually detached with tweezers and dried on paper trays at room temperature $\left(20\right.$ to $\left.25^{\circ} \mathrm{C}\right)$ for two to three days, until complete anther dehiscence and pollen drying. The anthers were placed in cotton-lined glass jars, cotton-lined, kept for up to five days in a desiccator containing silica gel, and stored in a refrigerator at $4{ }^{\circ} \mathrm{C}$.

For in vitro pollen germination, a culture medium was used containing $10 \%$ sucrose $+1 \%$ agar, according to Franzon, Corrêa, and Raseira (2005). The reagents were mixed in distilled water and heated in a microwave until the total dilution of the culture medium components. Still warm, it was poured into slides containing two PVC rings of $21 \mathrm{~mm}$ in diameter and $3 \mathrm{~mm}$ in height (observation unit), an adaptation to replace an excavated slide. When the culture medium had solidified, the pollen was sprinkled with a brush. The slides were placed in Petri 
dishes containing moistened paper and incubated in a B.O.D. chamber at $25 \pm 1{ }^{\circ} \mathrm{C}$ for $6 \mathrm{~h}$ with an absence of light.

The pollen grains were counted in an optical microscope, and those with an emitted pollen tube exceeding the diameter of the pollen grain itself were considered to be germinated (Franzon et al., 2005). The experimental design was completely randomized, with fourteen treatments in Dois Vizinhos and eleven in Pato Branco. Each treatment corresponded to pollen collected from a plant. Three replications, with an average percentage of two observation units were used. The data were subjected to homogeneity and normality of variance tests and, after this, the Scott-Knott test was applied to group the averages, using the R software (R Core Team, 2016).

\section{Results and Discussion}

In Pato Branco, flowering in the 2014/2015 cycle began from the second week of October. The flowering of the 2015/2016 and 2016/2017 cycles began in the second week of September and lasted until the first or second week of November, respectively (Figure 2). In Dois Vizinhos, feijoa flowering began in the first week of September and continued until the end of November, except for the 2016/2017 cycle, when plants flowered until December. The full flowering occurred between mid-October through to mid-November in most plants. In addition, we observed a variation of this characteristic among the progenies (Figure 2) and a more pronounced variation within the progenies (data not shown), probably due to genetic segregation. In Pato Branco, $96.7 \%$ of the plants flowered in the first evaluated cycle (2014/2015), and $100 \%$ in the two subsequent cycles $(2015 / 2016$ and 2016/2017). In Dois Vizinhos, these percentages were $35 \%, 56.7 \%$ and $88 \%$, respectively.

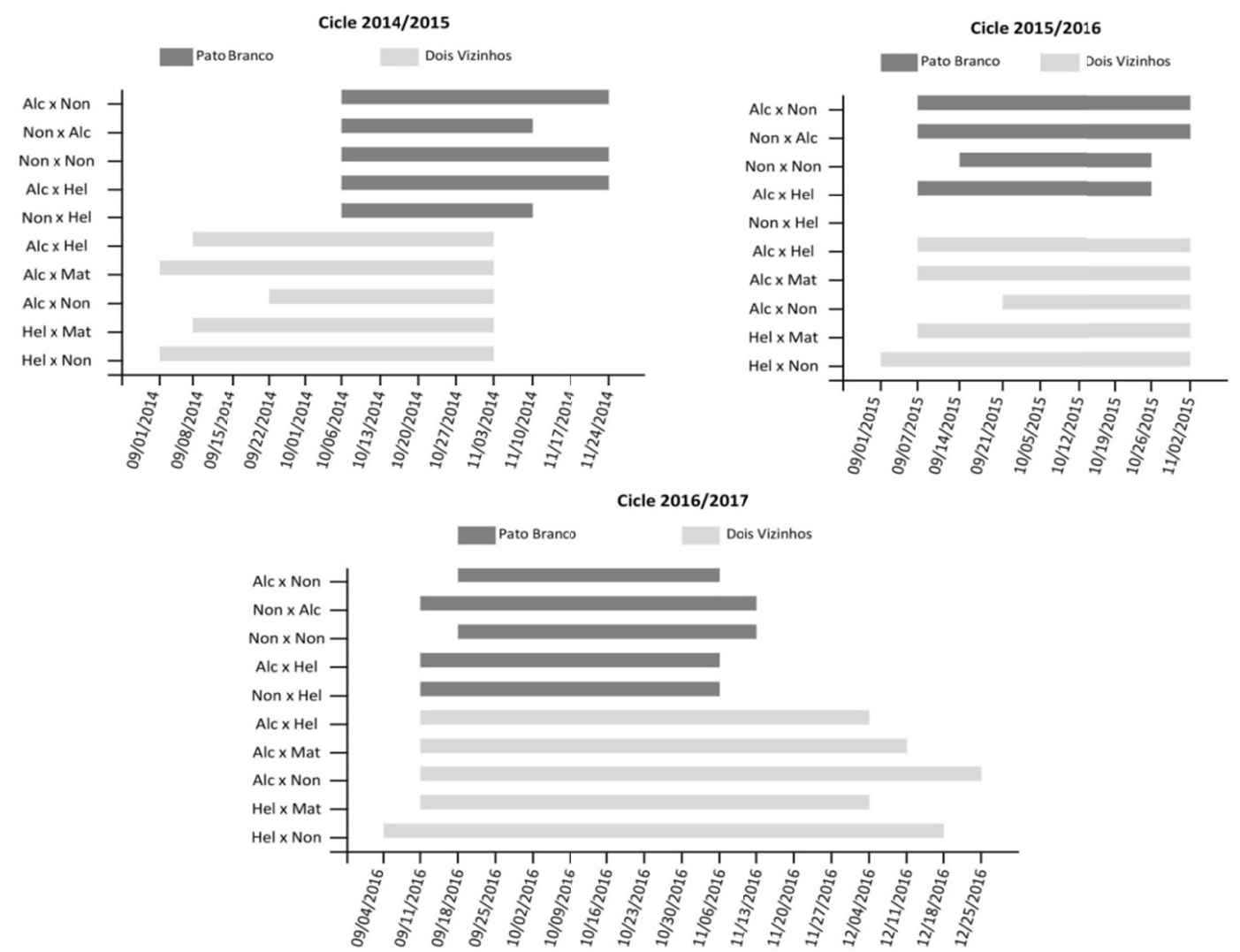

Figure 2. Flowering period (gray-hatched cells) of feijoa progenies in Pato Branco and Dois Vizinhos in the 2014/2015, 2015/2016 and 2016/2017 cycles, based on weekly evaluations. The first column indicates the cross that gave rise to the plants. Alc: Alcêntara; Hel: Helena; Mat: Mattos; Non: Nonante

The pollen germination percentage was $28 \%$ and $8 \%$ for Pato Branco and Dois Vizinhos (Table 1), respectively, which is considered low when compared to other studies (Franzon et al., 2005; Santos et al., 2007).

The effective fruit set in the 2015/2016 cycle in Pato Branco showed differences among the progenies and the three methods of pollination used (self-pollination, cross-pollination and open pollination) (Figure 3A). In total 286 fruits were obtained from 783 pollinated flowers, in 28 of the 58 plants that flowered in this cycle. 
The method of pollination with the most effective fruit set was manual cross-pollination, regardless of the assessed progenies, varying the fruit set from $94 \%$ to $50 \%$, with an average of $70 \%$ (Figure $3 \mathrm{~A}$ ). In manual self-pollination, the effective fruit set reached $20 \%$, but the Nonante $\times$ Nonante progeny did not produce fruits, which shows that the progenies are self-incompatible, a characteristic inherited from the progenitor that has this behavior (Ducroquet et al., 2008). In the other progenies, the fruit set was effective with self-pollination, ruling out the existence of total self-incompatibility. However, there may be a gradient of self-incompatibility, as previously reported for the species (Patterson, 1990), since the plants showed fruit set with self-pollination, although it was smaller than with crossed-pollination. The open pollination varied from $19 \%$ to $34 \%$ (Figure $3 \mathrm{~A})$.

In Dois Vizinhos, in the 2015/2016 cycle, it was also possible to verify the existence of differences between the progenies and the three methods of pollination used. There was a total of 46 fruits from the 371 pollinated flowers, in the 13 of 34 plants that flowered. The pollination method that led to the greatest effective fruit set was also manual cross-pollination, varying from $72 \%$ (Helena $\times$ Nonante) to $100 \%$ (Alcântara $\times$ Nonante and Alcântara $\times$ Helena) (Figure 3B). With self-pollination, only Helena $\times$ Nonante had $35 \%$ effective fruit set. Such a result may be due to the fact that the matrix cultivars of this crossing are self-compatible. The other progenies did not produce fruits through this method of pollination, showing that these other progenies may not be self-compatible. The effective fruit set for open pollination in Dois Vizinhos varied from 4 to $11 \%$ (Figure 3B). On average, the effective fruit set of open pollination was 14 times smaller than that of manual cross-pollination, which, added to the low rates of pollen viability $(8.0 \%)$ in these plants (Table 1$)$, resulting in a low effective fruit set.

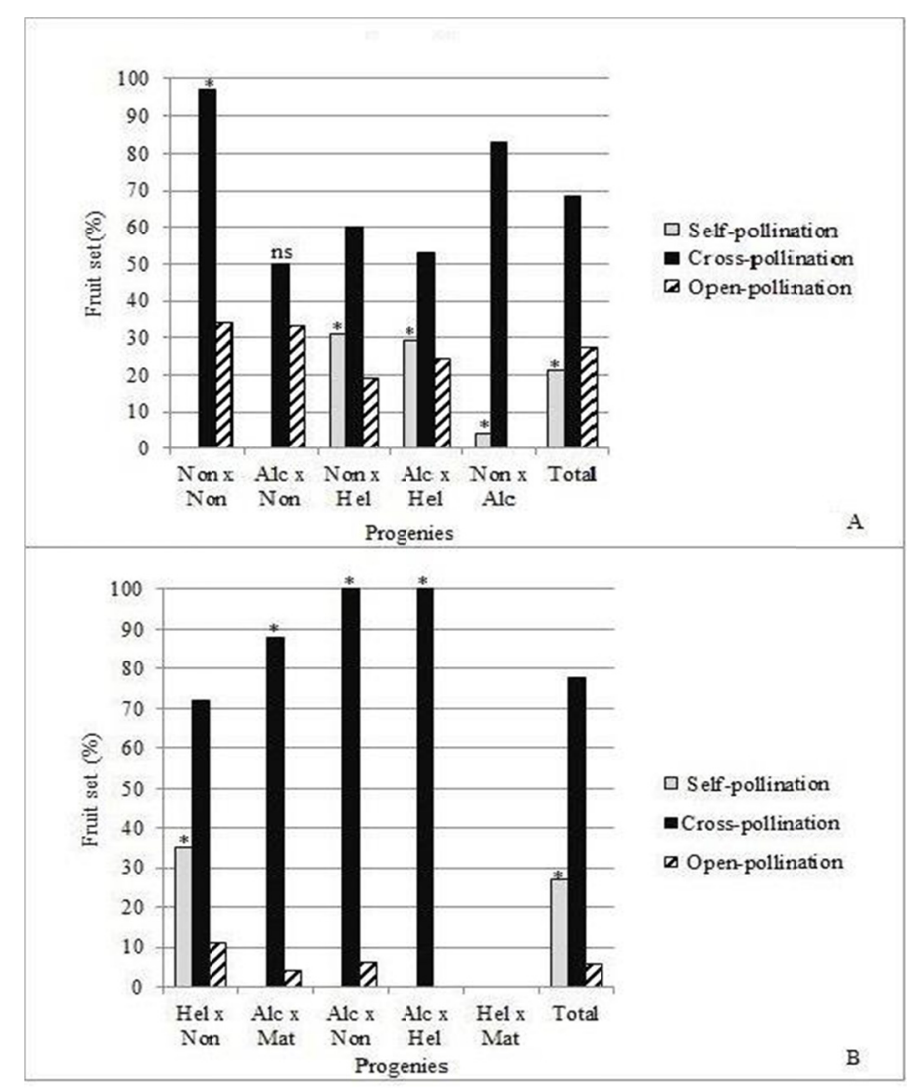

Figure 3. Fruit set of progenies by pollination method in feijoa for the $2015 / 2016$ cycle in Pato Branco (A) and Dois Vizinhos (B), Paraná, Brazil. * = Significant association $(\mathrm{p}<0.01)$ in contingency analysis with chi-square test; ns = not significant. Alc: Alcêntara; Hel: Helena; Mat: Mattos; Non: Nonante

Ducroquet et al. $(2007,2008)$ reported that the cultivars Alcântara, Helena, Mattos and Nonante begin flowering in early November under the conditions of São Joaquim, SC, Brazil (1,300 m altitude), and may vary from year to year. Nevertheless, the flowering observed in Pato Branco, with 730 meters of altitude, and, Dois Vizinhos, located 530 meters above sea level in early September, was at least one month before the elite cultivars in São Joaquim. In the Bogotá region, under Andean conditions, at 2600 meters of altitude, flowering occurs in two 
periods, February and September, resulting in two harvest events, in May-June representing $70 \%$ of the harvest and January, representing only 30\% (Ramírez \& Kallarackal, 2018). This shows the interference of the weather variations found in those regions. According to Ramírez and Kallarackal (2018), precipitation has a clear effect on leaf development and the development of feijoa fruits, but does not influence floral induction. Parra-Coronado, Fischer and Chaves-Cordoba (2015) stated that the largest thermal sum can reduce the schedule of feijoa phenophases. Thus, the possible cause for this early flowering may be linked to temperature, in São Joaquim, there was an average of $13{ }^{\circ} \mathrm{C}$ for September and $15{ }^{\circ} \mathrm{C}$ for October, while the average for these months in Pato Branco was $18{ }^{\circ} \mathrm{C}$ and $20^{\circ} \mathrm{C}$ and, in Dois Vizinhos, $20{ }^{\circ} \mathrm{C}$ and $24{ }^{\circ} \mathrm{C}$ (Figure 1). In studies of feijoa adaptability, Ducroquet et al. (2000) believed that the available cultivars could be cultivated only in the high-altitude regions in the states of Paraná, Santa Catarina and Rio Grande do Sul. Thus, there is, for the sites in the current study, a difference of at least two degrees in average temperature, which may have influenced the early flowering.

The delay in the reproductive period observed in Dois Vizinhos, can be related to the crossing adaptation to climatic conditions, since the progenies come from elite matrixes from places of altitude in Santa Catarina (Ducroquet et al., 2007, 2008). Therefore, it is possible to infer a better adaptation for the species in Pato Branco compared with Dois Vizinhos, explained mostly by the higher altitude and, consequently, lower average temperature. Another fact that corroborates that there is a better adaptation of feijoa in Pato Branco than in Dois Vizinhos is the smaller flowering heterogeneity. For Pato Branco, the average time of flowering in the three assessed cycles was 7.4 weeks, while for Dois Vizinhos it was 9.7 weeks (Figure 2). When plants from a temperate climate are cultivated in regions with a mild winter, they show several developmental anomalies, such as extended flowering period, deformation of the stigma, low pollen quality, erratic flowering and low effective fruit set (Petri \& Leite, 2004; Oukabli \& Mahhou, 2007). In general, the more the species is adapted to the cultivation site, the more homogeneous and compact its flowering is. The flowering was most abundant and compact in Pato Branco, which may be due to the occurrence of colder periods, which have a greater similarity to the place of origin of its genitors.

In areas where the species naturally occurs, pollen germination has been observed, by several studies, to always be greater than 69\% (Franzon et al., 2005; Santos et al., 2007), although a wide variation of pollen germination was observed in the review conducted by Ramírez and Kallarackal (2017). In the present study, the low pollen germination (Table 1) may be evidence that the climatic conditions of the regions (Pato Branco and Dois Vizinhos) are not adequate for the studied genotypes. Temperatures above $30{ }^{\circ} \mathrm{C}$ decrease pollen viability considerably (Franzon et al., 2005). The temperature variation recorded in Dois Vizinhos by a weather station from INMET (National Institute of Meteorology) was high, with minimum of $2.1^{\circ} \mathrm{C}$ and a maximum of $36{ }^{\circ} \mathrm{C}$ recorded in September 2015, and the temperature variation recorded in Pato Branco by Simepar (Meteorological System of Paraná) showed a minimum of $2.8^{\circ} \mathrm{C}$ and maximum of $33.7^{\circ} \mathrm{C}$. This could justify the difference in the pollen germination percentages found between the genotypes located in Dois Vizinhos and Pato Branco.

In addition, the elite matrixes used for performing the crossings assessed in this study are cultivars adapted to areas 1,200 meters above sea level (Ducroquet et al., 2007, 2008), with average temperatures below those recorded at the sites in the present study. Therefore, the progenies of these crossings, in places too distinct from their origin, show less adaptation which is the case for pollen viability.

When genotype performance was assessed, in general, those that had the Helena variety as one of their genitors had a higher rate of pollen germination, which is a characteristic of interest that can be selected in the segregating populations (Table 1). This variable comes from crossing with the cv. Unique (Ducroquet et al., 2007), which belongs to the Uruguay type. This feijoa type comes from that geographical area with higher temperature averages when compared to São Joaquim, SC, Brazil, place that holds the Brazilian type of feijoa. 
Table 1. Percentage of in vitro pollen germination of feijoa progenies in the 2015/2016 cycle for Pato Branco and Dois Vizinhos, PR

\begin{tabular}{lll}
\hline \multirow{2}{*}{ Progenies } & \multicolumn{2}{c}{ Pollen germination (\%) } \\
\cline { 2 - 3 } & Pato Branco & Dois Vizinhos \\
\hline Helena $\times$ Nonante & - & $4.2 \mathrm{c}$ \\
Helena $\times$ Nonante & - & $16.8 \mathrm{a}$ \\
Helena $\times$ Nonante & - & $9.1 \mathrm{~b}$ \\
Helena $\times$ Nonante & - & $6.0 \mathrm{c}$ \\
Helena $\times$ Nonante & - & $4.9 \mathrm{c}$ \\
Helena $\times$ Nonante & - & $5.8 \mathrm{c}$ \\
Alcântara $\times$ Mattos & - & $3.8 \mathrm{c}$ \\
Alcântara $\times$ Mattos & - & $4.7 \mathrm{c}$ \\
Alcântara $\times$ Mattos & - & $4.2 \mathrm{c}$ \\
Alcântara $\times$ Nonante & $12.5 \mathrm{c}$ & $5.2 \mathrm{c}$ \\
Alcântara $\times$ Helena & $48.5 \mathrm{a}$ & $9.7 \mathrm{c}$ \\
Alcântara $\times$ Helena & $34.2 \mathrm{~b}$ & $17.3 \mathrm{a}$ \\
Alcântara $\times$ Helena & $22.9 \mathrm{c}$ & $10.4 \mathrm{~b}$ \\
Alcântara $\times$ Helena & $17.6 \mathrm{c}$ & $9.4 \mathrm{~b}$ \\
Nonante $\times$ Helena & $42.1 \mathrm{a}$ & - \\
Nonante $\times$ Helena & $29.2 \mathrm{~b}$ & - \\
Nonante $\times$ Helena & $20.6 \mathrm{c}$ & - \\
Nonante $\times$ Alcântara & $37.1 \mathrm{~b}$ & - \\
Nonante $\times$ Alcântara & $15.6 \mathrm{c}$ & - \\
Nonante $\times$ Nonante & $24.2 \mathrm{c}$ & - \\
\hline Means & 27.7 & 8.0 \\
\hline CV $(\%)$ & 22.5 & 13.8 \\
\hline
\end{tabular}

Note. * Means of each treatment followed by equal letters in the columns do not differ (Scott-Knott's test, $\mathrm{p} \leq$ $0.05)$.

The effective fruit set originating from manually pollinated flowers was greater than the one obtained by open pollination for both the studied sites (Figure 3), which is consistent with what was observed by Finatto et al. (2011), who noticed a significant reduction regarding the effective fruit set for open pollination when compared to manual cross-pollination. However, in Dois Vizinhos, there was a significant reduction in the effective fruit set rate for open pollination $(5.8 \%)$ when compared with Pato Branco (27.5\%). The combining of the analyses from both experiments performed in Dois Vizinhos and in Pato Branco revealed that, in addition to the pollen viability issue, there may have been a lack of pollinators 1, particularly birds (Ducroquet \& Hichel, 1997; Mattos, 1986; Ramírez \& Kallarackal, 2017; Thorp \& Bieleski, 2002) and bumblebees. This corroborates with the hypothesis that a lack of pollinators can result in low production and varies according to the locations, therefore complementary manual pollination is necessary (Patterson, 1990). This fact can explain what occurred in Dois Vizinhos, since, with open pollination, the effective fruit set was lower than the manual pollination treatments (Figure 3A). In addition, it is worth mentioning that the pollinator restrictions results in the natural variation of pollen quantity deposited on the flower stigma, which influences the number of seeds per fruit and, as a consequence, the reduction of fruit seed number is associated with the ease of abortion (Stephenson, 1981). High precipitation and low temperatures decrease the abundance of pollinators (bumblebees) and the period of stigma receptivity may be reduced, in addition to mechanical damage to the flowers (Rom, 1970). In the period of feijoa flowering in Pato Branco and Dois Vizinhos, in September and October, the precipitation was 80.4 and $205.8 \mathrm{~mm}$ for Pato Branco, and 42.8 and $185.6 \mathrm{~mm}$ in Dois Vizinhos, respectively (Figure 1), which may not justify the low effective fruit set.

The open pollination was not enough to achieve the potential fruit production in the assessed plants, suggesting that pollination is a factor to be considered in species adaptation to regions of marginal occurrence and cultivation, requiring manual pollination or the availability of pollinators to obtain good fruit yields.

\section{Conclusion}

In areas of marginal occurrence of the species, the flowering period of feijoa begins earlier and is extended compared with adapted areas. Low pollen viability and pollination deficiency were observed in areas of marginal occurrence of the species, which caused low fruit set. We suggest that manual pollination should be used, since 
with cross-pollination there was an effective fruiting compatible with the need for commercial production. More detailed investigations should be carried out to identify pollinator agents as well as their efficiency in pollination.

\section{Acknowledgements}

We are grateful to Conselho Nacional de Desenvolvimento Científico e Tecnológico (CNPq) for the financial resources (proj 477826/2013-0) and scholarship to RON.

\section{References}

Amarante, C.V. T. (2017). Cultivo de feijoa (Acca sellowiana) na Nova Zelândia: Da produção à pós-colheita. Serie Actividades de Difusión, 772, 26-37. Retrieved from http://www.ainfo.inia.uy/digital/bitstream/ item/6657/1/SAD-772.pdf

Beyhan, O., \& Eyduran, S. P. (2011). Determination of promising native Feijoa (Feijoa sellowiana Berg.) genotypes from Sakarya Region in Turkey. Scientific Research and Essays, 6(19), 4104-4108. https://doi.org/10.5897/SRE11.558

Bhering, S. B., Santos, H. G., Bognola, I. A., Cúrcio, G. R., Carvalho Junior, W. D., Chagas, C. D. S., ... Silva, J. D. S. (2008). Mapa de solos do Estado do Paraná. Rio de Janeiro: EMBRAPA/IAPAR.

Coradin, L., Siminski, A., \& Reis, A. (2011). Espécies Nativas da Flora Brasileira de Valor Econômico Atual ou Potencial. Brasília: Ministério do Meio Ambiente.

Donazzolo, J., Ornellas, T. S., Bertoldo, J. G., \& Nodari, R. O. (2014). Performance of segregating populations of feijoa cultivated under the agroforestry systems in southern Brazil. African Journal of Agricultural Research, 9(45), 3305-3312. https://doi.org/10.5897/AJAR2014.8573

Ducroquet, J. P. H. J., \& Hickel, E. R. (1997). Birds as pollinators of Feijoa (Acca sellowiana Bera). International Symposium on Myrtaceae, 452, 37-40. https://doi.org/10.17660/ActaHortic.1997.452.5

Ducroquet, J. H., Hickel, E. R., \& Nodari, R. O. (2000). Goiabeira-serrana (Feijoa sellowiana). Série Frutas nativas 5, Funep.

Ducroquet, J. P. H. J., \& Hickel, E. R. (1991). Fenologia da goiabeira serrana (Feijoa sellowiana Berg) no alto vale do Rio do Peixe, Santa Catarina. Revista Brasileira de Fruticultura, 13(3), 313-320.

Ducroquet, J. P. H. J., Nunes, E. D. C., Guerra, M. P., \& Nodari, R. O. (2008). Novas cultivares brasileiras de goiabeira serrana: SCS 414-Mattos e SCS 415-Nonante. Agropecuária Catarinense, 21(2).

Ducroquet, J. P. H. J., Santos, K. D., Andrade, E. D., Boneti, J. I., Bonin, V., \& Nodari, R. O. (2007). As primeiras cultivares brasileiras de goiabeira serrana: SCS 411 Alcântara e SCS 412 Helena. Agropecuária Catarinense, 20, 77-80.

EMBRAPA (Centro Nacional de Pesquisa de Solos). (2006). Sistema brasileiro de classificação de solos. EMBRAPA Produção de Informação, Brasília.

Finatto, T., Dos Santos, K. L., Steiner, N., Bizzocchi, L., Holderbaum, D. F., Ducroquet, J. P., ... Nodari, R. O. (2011). Late-acting self-incompatibility in Acca sellowiana (Myrtaceae) 1. Australian Journal of Botany, 59(1), 53-60. https://doi.org/10.1071/BT10152

Fischer, G., Ramírez, F., \& Almanza-Merchán, P. J. (2012). Inducción floral, floración y desarrollo del fruto. In G. Fischer (Ed.), Manual para el cultivo de frutales en el trópico (pp. 120-140). Bogotá: Produmedios.

Franzon, R. C., Corrêa, E. R., \& Raseira, M. D. C. B. (2005). In vitro pollen germination of feijoa (Acca sellowiana (Berg) Burret). Crop Breeding and Applied Biotechnology, 5(2). https://doi.org/10.12702/19847033.v05n02n02

Hammer, Ø., Harper, D. A. T., \& Ryan, P. D. (2001). Paleontological statistics software: Package for education and data analysis. Palaeontologia Electronica, 4.

IAPAR. (2017). Cartas Climáticas do Paraná. Retrieved from http://www.iapar.br/modules/conteudo/ conteudo.php?conteudo $=604$

Lorenzini, A. R., Boff, M. I., Rech, T. D., \& Boff, P. (2007). Fitogeografia da goiabeira serrana no Planalto Serrano Catarinense. Agropecuária. Catarinense, 20, 86-89.

Mattos, J. R. (1986). A goiabeira serrana. Instituto de Pesquisas de Recursos Naturais Renovaveis, Porto Alegre. 
Miranda, C., Santesteban, L. G., \& Royo, J. B. (2013). Evaluation and fitting of models for determining peach phenological stages at a regional scale. Agricultural and Forest Meteorology, 178, 129-139. https://doi.org/ 10.1016/j.agrformet.2013.04.016

Oukabli, A., \& Mahhou, A. (2007). Dormancy in sweet cherry (Prunus avium L.) under Mediterranean climatic conditions. Biotechnology, Agronomy, Society and Environment, 11(2), 133-139.

Parra-Coronado, A., Fischer, G., \& Camacho-Tamayo, J. H. (2015). Development and quality of pineapple guava fruit in two locations with different altitudes in Cundinamarca, Colombia. Bragantia, 74(3), 359-366. https://doi.org/10.1590/1678-4499.0459

Parra-Coronado, A., Fischer, G., \& Chaves-Cordoba, B. (2015). Tiempo térmico para estados fenológicos reproductivos de la feijoa (Acca sellowiana (O. Berg) Burret). Acta Biológica Colombiana, 20(1).

Patterson, K. J. (1990). Effects of pollination on fruit set, size, and quality in feijoa (Acca sellowiana (Berg) Burret). New Zealand Journal of Crop and Horticultural Science, 18(2-3), 127-131. https://doi.org/ 10.1080/01140671.1990.10428082

Petri, J. L., \& Leite, G. B. (2004). Consequences of insufficient winter chilling on apple tree bud-break. VII International Symposium on Temperate Zone Fruits in the Tropics and Subtropics, 662, 53-60. https://doi.org/10.17660/ActaHortic.2004.662.4

Team, R. C. (2016). R: A language and environment for statistical computing. R Foundation for Statistical Computing, Vienna, Austria. Retrieved October, 14, 2017, from https://www.R-project.org

Ramírez, F., \& Kallarackal, J. (2017). Feijoa [Acca sellowiana (O. Berg) Burret] pollination: A review. Scientia Horticulturae, 226, 333-341. https://doi.org/10.1016/j.scienta.2017.08.054

Ramírez, F., \& Kallarackal, J. (2018). Phenological growth stages of Feijoa [Acca sellowiana (O. Berg) Burret] according to the BBCH scale under tropical Andean conditions. Scientia Horticulturae, 232, 184-190. https://doi.org/10.1016/j.scienta.2017.12.059

Rom, R. C. (1970). Variety and cultural considerations necessary to assure adequate pollination in apple orchards. The indispensable pollinators (pp. 219-225). Pollination Conference, IX ${ }^{\text {th }}$, West Lafayette.

Santos, K. L. D., Donazzolo, J., Guries, R. P., Peroni, N., \& Nodari, R. O. (2018). Participatory research with Acca sellowiana: Stimulating the breeding process for a native fruit species. Agroecology and Sustainable Food Systems, 42(4), 432-447. https://doi.org/10.1080/21683565.2017.1373383

Santos, K. L. D., Lenzi, M., Caprestano, C. A., Dantas, A. C. D. M., Ducroquet, J. P. H. J., Nodari, R. O., Guerra, M. (2007). Evidência da atuação do sistema de auto-incompatibilidade tardia em Acca sellowiana (Berg) Burret. (Myrtaceae). Revista Brasileira de Fruticultura, 29(1). https://doi.org/10.1590/S010029452007000100026

Stephenson, A. G. (1981). Flower and fruit abortion: Proximate causes and ultimate functions. Annual Review of Ecology and Systematics, 12(1), 253-279. https://doi.org/10.1146/annurev.es.12.110181.001345

Thorp, G., \& Bieleski, R. L. (2002). Feijoas: Origins, cultivation and uses. HortResearch.

Vignale, B., \& Bisio, L. (2005). Selección de frutales nativos en Uruguay. Agrociencia, 9(1-2), 35-39.

Xiong, H., Zou, F., Yuan, D., Zhang, X., \& Tan, X. (2016). Orthogonal test design for optimising the culture medium for in vitro pollen germination of feijoa (Acca sellowiana cv. Unique). New Zealand Journal of Crop and Horticultural Science, 44(3), 192-202. https://doi.org/10.1080/01140671.2016.1174945

Yezhov, V. N., Smykov, A. V., Smykov, V. K., Khokhlov, S. Y., Zaurov, D. E., Mehlenbacher, S. A., ... Funk, C. R. (2005). Genetic resources of temperate and subtropical fruit and nut species at the Nikita Botanical Gardens. HortScience, 40(1), 5-9.

\section{Copyrights}

Copyright for this article is retained by the author(s), with first publication rights granted to the journal.

This is an open-access article distributed under the terms and conditions of the Creative Commons Attribution license (http://creativecommons.org/licenses/by/4.0/). 